\title{
Research on the Urban Adaptation of Landless Peasants during the Construction of New Urban Districts-A Case Study of Zhanghe New District in Jingmen City, Hubei Province, China
}

\author{
Shiyu Yang \\ Urban Studies Department, The University of Sheffield, Sheffield, UK \\ Email: yangshiyuchn@outlook.com
}

How to cite this paper: Yang, S. Y. (2021). Research on the Urban Adaptation of Landless Peasants during the Construction of New Urban Districts-A Case Study of Zhanghe New District in Jingmen City, Hubei Province, China. Open Journal of Social Sciences, 9, 417-439.

https://doi.org/10.4236/jss.2021.910029

Received: September 29, 2021

Accepted: October 26, 2021

Published: October 29, 2021

Copyright $\odot 2021$ by author(s) and Scientific Research Publishing Inc. This work is licensed under the Creative Commons Attribution International License (CC BY 4.0).

http://creativecommons.org/licenses/by/4.0/

\begin{abstract}
In China, the construction of new urban districts has now become the main route to urbanisation. The construction of new urban districts, mainly through the expropriation of rural land, has created many landless peasants in the process. This study aims to investigate the real situation of urban adaptation of landless peasants due to the construction of new urban districts. This is followed by a further in-depth analysis of the reasons affecting the adaptation of landless peasants to the city, and some targeted policy or institutional recommendations. Most of the current studies have focused on the macro level and lack the micro level of the individual landless peasants. And the research methods are only quantitative or only qualitative. Therefore, this study introduces the concept of "self-identity" and focuses on the individual feelings of landless peasants. A combination of qualitative and quantitative methods was used to conduct the study. The study found that, in terms of the economy, peasants face difficulties in finding employment, low income and increased expenses in the new urban districts. Although social security benefits have improved, they are still lower than those of urban residents. Socially, peasants' social networks are limited, and their daily activities are not rich. As a result, self-identity is blurred, and inter-generational differences emerge.
\end{abstract}

\section{Keywords}

NUDs, Landless Peasants, Urban Adaptation, Urbanisation

\section{Introduction}

China's urbanisation is booming. China's future new urbanisation path will be 
ecological, environmentally friendly, innovative, and smart. But the urbanisation process will put increasing strain on land supply (Fang, 2009). In this context, some localities use the creation of new districts to secure land for urbanisation (Zhai et al., 2006). Since the development of Pudong New District, new district planning and development has exploded, with localities following suit (Wang, 2011). There will be 19 national, 33 provincial, and 13 municipal new urban districts by July 2020 (Chanyeguihua.com, 2021).

China's urbanisation rate will reach $60 \%$ by 2020 and $70 \%$ by 2050 (National Development and Reform Commission, 2016). Many rural residents lost their land due to urbanisation and became new urban residents, often without farmland, jobs, income or security (Wang, Zhan, \& Jiang, 2018). This group is also highly susceptible to social conflicts. According to the 2013 China Labour Market Report, $14.41 \%$ of landless peasants were unemployed at home, and $60 \%$ were struggling to make ends meet (Lai, 2011). Over 100 people were killed in 871 mass incidents between 2001 and 2014, according to the China Rule of Law Development Report (Li \& Tian, 2014). Thus, studying landless peasants is important for social stability and development. Thus, the problem of urban adaptation of landless peasants in the construction of new urban districts was chosen.

The current research on landless peasants in China focuses on policies and institutions at the macro level, but not on individuals. The concept of landless peasants is muddled with internal migration. Landless peasants in NUDs have also been overlooked. This research seeks to understand how landless peasants adapt to new urban districts. The study examines the urbanisation of landless peasants and its underlying causes using quantitative and qualitative research methods. The study also makes feasible suggestions. Jingmen City, Hubei Province, China was chosen as the study area. Several research objectives are designed to achieve this goal. They are:

1) to critically review the literature on the urban adaptation status of landless peasants;

2) to explore the urban adaptation of landless peasants in the construction of the Zhanghe New Area (through a questionnaire survey);

3) to analyse the factors that influence the urban adaptation of landless peasants in the Zhanghe New Districts (through cross-tabulation of interview and questionnaire data);

4) to explore effective approaches that can help landless peasants in the Zhanghe New Districts adapt better to the city;

5) to synthesise the findings of the study and draw conclusions, and provide some possible recommendations.

\section{Literature Review}

\subsection{Definition of Relevant Concepts}

\subsubsection{New Urban Districts (NUDs)}

New Urban Districts (NUDs) are a significant support and spatial expression of 
China's urbanisation process (Zhu \& Zhou, 2013). New urban development has recently played an important role in city growth. The NUDs have a significant impact on the city's industrial, demographic, and spatial evolution (Shan \& Huang, 2013). The Garden City concept originated the NUD concept internationally (Howard \& Osborn, 2006). Governments and regions have found it difficult to avoid this option. Institutional, planning, and policy tools are important factors in determining NUDs.

China's NUD study began late. It can be traced back to Beijing's planning and construction's Liang Chen schemel (Wu, 2005), based on organic evacuation theory and the construction of new districts. Following the reform and opening, NUDs such as SEDs, EDDs, INDs, and industrial parks have gradually emerged. Wu Wenxin, Yang Yongchun, et al. summarised two basic NUD construction models. Building a new city in an undeveloped area. The other is the economic, social, and cultural assimilation of the surrounding suburbs due to the mother city's radiating effect (Wu et al., 2005). This paper's discussion of new urban districts fits the second model.

People in the development area, especially peasants who have lost their land due to NUD construction, are rarely considered in NUD research. The idea of urbanisation was first proposed after the 18th Chinese National Congress. The new type of urbanisation, according to Chinese Premier Li Keqiang, is "an urbanisation with people at its core" (Zhang, 2013). Thus, the research topic chosen was peasants who lost their land due to NUD construction.

\subsubsection{Landless Peasants}

The urbanisation path is achieved through a change in the land's nature. In other words, building NUDs necessitates large-scale rural land expropriation, leading to landlessness. The term "Landless Peasants' in this article comes from Heger's analysis of shidi nongmin". The term "Landless Peasants" is not only a direct translation of the Chinese designation, but also a reflection of how rural people see themselves and others (Heger, 2020). Contemporary Chinese "peasants" encompass social, cultural, political, and identity categories beyond the surface-level administrative meaning of peasant occupation and rural hukou. These include political unsuitability, social class, and quality (Schneider, 2015).

\subsection{Compensation Policy for Landless Peasants in China}

On 29 August 1998, the newly amended Land Administration Law was adopted at the fourth meeting of the Standing Committee of the Ninth National People's Congress and came into force on 1 January 1999. Article 47 of the Law stipulates that compensation for the expropriation of arable land shall include compensation for land, resettlement allowance and compensation for land attachment and seedlings.

The land compensation fee for the expropriation of arable land shall be six to ten times the average annual production value of the arable land in the three years prior to the expropriation. 
The resettlement allowance for the expropriation of arable land is calculated according to the number of agricultural populations to be resettled. The number of agricultural populations to be resettled is calculated by dividing the amount of arable land expropriated by the average amount of arable land occupied by each person in the expropriated unit before the expropriation. The rate of resettlement allowance for each agricultural population to be resettled is four to six times the average annual production value of the arable land in the three years before the expropriation. However, the maximum amount of resettlement subsidy per hectare of expropriated arable land shall not exceed 15 times the average annual production value of the three years prior to the expropriation. The sum of the land compensation fee and the resettlement subsidy shall not exceed 30 times the average annual production value of the land in the three years prior to the expropriation (Ren \& Xie, 2008).

\subsection{Current Research on Urban Adaptation of Landless Peasants}

Western academics are very concerned about the coercive nature of state-led urbanisation and the plight of landless peasants and are generally critical of China's path to rural modernisation. However, some scholars have emphasised the agency of peasants despite their structural disadvantage (Lora-Wainwright, 2014; Wang \& Christiansen, 2019; Heger, 2020). Additionally, the impact of urbanisation on people depends on both individual and regional factors (Chen, 2020; Rosenberg, 2013) and the fact that individuals' assessments of experienced changes can vary significantly (Bray, 2013; Heger, 2018). Western media are also frequently negative, portraying landless peasants as victims of China's urbanisation frenzy (Jin, 2017; Johnson, 2013; Heger, 2020).

There is much research in Chinese academia on the issue of landless peasants. A decade ago, most research on landless peasants in China focused on resettlement, land compensation, protection of rights and interests, employment and social security. However, these studies raised some fundamental issues: poor employment, low income, lack of social security, lack of willingness to decentralise, and uncertainty about future life expectations (Cheng \& Dong, 2004; Ge, 2004; Li, 2004; Zhang, 2004).

Most research on landless peasants has been macro-focused, with little micro-focus. However, micro studies of landless peasants in China have increased in recent years, focusing on their identity and urban adjustment ( $\mathrm{Wu} \& \mathrm{Qin}$, 2008; Wang \& Zhu, 2014). Many studies have examined landless peasants' identities and the psychological barriers that hinder their urban adaptation (Chai, Li, \& Liu, 2021; Tang \& Xie, 2018). It is a result of land loss and urbanisation. In order to move from peasant to citizen, one must redefine one's self, re-answer the question "who am I?" In other words, landless peasants must reclaim their social position of "self" in the context of landlessness and urbanisation. For landless peasants, self-identity is a dimension of urban adaptation. The study seeks to understand the psychological shocks caused by dramatic social change and how individuals interact with society. 
Many academic studies on landless peasants have focused on "internal immigration" (Mocetti \& Porello, 2010). These are landless peasants relocated to urban areas or other places due to land acquisition. However, this study focuses on a different type of landless peasant caused by NUD construction. Unlike rural migrants, landless peasants were resettled in situ and did not travel to the city; the city came to them (Chen et al., 2014). So, in terms of living environment and residential density, landless peasants' neighbourhoods change little before and after resettlement. Also, building new urban districts takes time. Instead of being relocated directly to the old city, landless peasants in NUDs face new challenges, such as inadequate public facilities and services.

In conclusion, a unified indicator system to measure the level of urban adaptation of landless peasants has not yet been established. The factors affecting landless peasants' urban adaptation have not been studied from the perspectives of individuals, communities, or governments. However, the micro-feelings of landless peasants are often overlooked, as is their self-identification status. The many causes of landlessness in China have led scholars to focus on landless peasants resettled elsewhere, ignoring those resettled locally due to new rural construction. Unlike relocated migrants, these peasants face no urban discrimination and must focus on their psychological transition. Moreover, most empirical research focuses on the urbanisation of eastern coastal cities, while research on landless peasants in the central region has been limited. This study focuses on landless peasants in Zhanghe New District, Jingmen City, central China, in light of increasing urbanisation, new rural district construction, and landless peasants' urban adaptation issues. An empirical analysis of landless peasant urban adaptation status and characteristics is conducted, followed by countermeasures to promote landless peasant urban adaptation.

\section{Methodology}

\subsection{Research Design}

This article draws on the review and analysis of secondary literature, policy documents, and primary data collected in the field. Post-positivism is the research method used in this study. Landless peasants in Zhanghe New District, Jingmen City, Hubei Province, China, were studied qualitatively and quantitatively. Most previous research on landless peasants' identity and urban adaptation has been quantitative or qualitative in nature. The main reason for using a mix of qualitative and quantitative methods in this study is to get more precise results. Qualitative and quantitative methods are combined to compensate for their overlapping weaknesses. Statistics can provide a descriptive picture of landless peasants' urban adaptation. Qualitative methods can describe, explain, and verify quantitative results (Pope, Ziebland, \& Mays, 2000). In this way, the study can examine the actual situation of landless peasants' urban adaptation and the factors that influence their urban adaptation. The situation of the surveyed landless peasants was studied macro and micro, focusing on their peculiar 
feelings. The study's findings have important implications for the design of NUDs. More NUDs may help landless peasants adapt to urban life. The study's methodology is described below.

\subsection{Methods for Data Collection}

\subsubsection{Sampling}

The study area was selected in Zhanghe New District, Jingmen City, Hubei Province, China. The Zhanghe New District was officially launched on 8 December 2011. Zhanghe New Area is located in the western suburbs of Jingmen, Hubei Province, with a total area of 486 square kilometres. Zhanghe New Area has apparent advantages in terms of its location to take on the radiation of the main city, gather factor resources, promote economic development and seek new urban growth points. Since the establishment of Zhanghe New District, comprehensive rural land acquisition has been carried out within the functional area of the city (Zhanghe New District Management Committee, 2021). The target population was the landless peasants in the Zhanghe New District who were passively urbanised.

The sampling method for the quantitative study was random sampling. The sampling method for the qualitative study was stratified sampling, i.e. two interviewees were selected from each age group. The criteria for selecting the sample were that participants had to

1) have lost their land,

2) have lost their land as a result of urbanisation,

3) have been passively urbanised, and their land expropriated by the government rather than transferred.

\subsubsection{Survey Research and Data Analysis}

The survey questionnaire was adapted from well-known sociology and urban planning scholars, such as Zhang \& Tong (2006) and Han Dan (2019). However, because this research topic only includes landless peasants resettled during the NUD construction process, not all questions apply. So the researcher screened the questions for this topic. The questionnaire was divided into three sections: economic, social, and self-identity, with roughly ten questions per section. Approximately 302 questionnaires were distributed through personal visits and the Chinese social media app WeChat. There were a total of 244 valid questionnaires. The basic information of the valid sample collected is shown in Table 1.

The first step in the data analysis method analyses the distribution of options for each question in the questionnaire. The second step is to select some of the questions in the questionnaire for cross-tabulation and correlation analysis to produce data analysis results and graphs. However, the selection of questionnaire questions cannot be interpreted, and the factors influencing the urban adaptation of landless peasants cannot be explored in-depth. Therefore, a combination of semi-structured interviews and literature research is needed for further in-depth analysis. 
Table 1. Basic Information of participations.

\begin{tabular}{|c|c|c|c|}
\hline \multicolumn{4}{|c|}{ Basic Information of participations $(\mathrm{N}=244)$} \\
\hline & & Frequency & Percentage \\
\hline \multirow{3}{*}{ Gender } & Male & 121 & 49.6 \\
\hline & Female & 118 & 48.4 \\
\hline & Don't want to tell & 5 & 2 \\
\hline \multirow{6}{*}{ Age } & Under 20 years old & 0 & 0 \\
\hline & 21 to 30 years old & 28 & 11.5 \\
\hline & 31 to 40 years old & 93 & 38.1 \\
\hline & 41 to 50 years old & 78 & 32 \\
\hline & 51 to 60 years old & 40 & 16.4 \\
\hline & More than 60 years of age & 5 & 2 \\
\hline \multirow{5}{*}{ Degree of Education } & Primary school and below & 7 & 2.9 \\
\hline & Junior high school & 98 & 40.2 \\
\hline & High school or technical secondary school & 94 & 38.5 \\
\hline & College or Bachelor degree & 44 & 18 \\
\hline & Master degree or above & 1 & 0.4 \\
\hline \multirow{4}{*}{ Personal Annual Income } & Less than 10,000 yuan & 70 & 28.7 \\
\hline & 10,000 to 30,000 yuan & 76 & 31.1 \\
\hline & 30,000 to 60,000 yuan & 66 & 27 \\
\hline & More than 60,000 yuan & 32 & 13.1 \\
\hline \multirow{7}{*}{ Occupation } & Peasants & 30 & 12.3 \\
\hline & Migrant workers in cities & 76 & 31.1 \\
\hline & Freedom and individual workers & 62 & 25.4 \\
\hline & Work in enterprises and institutions & 27 & 11.1 \\
\hline & Students & 1 & 0.4 \\
\hline & Unemployed & 27 & 11.1 \\
\hline & Other & 21 & 8.61 \\
\hline
\end{tabular}

\subsubsection{Semi-Structured Interviews and Data Analysis}

The basic situation of self-identification and urban adaptation of landless peasants was analysed using questionnaires. The landless peasants' self-identity and urban adjustment were then explored in semi-structured interviews. To obtain sufficient, comprehensive, and in-depth data for each age group of survey participants. Face-to-face interviews were conducted with one representative from each age group and one member with special circumstances. A member of the study area's resettlement community was also interviewed. So, 11 interviews were conducted. The interviewees were chosen for their knowledge and activity to collect reliable data (Kirby, 2003). The researcher only needed to ask extended questions on critical aspects related to the topic during semi-structured interviews (Baumbusch, 2010). The basic information about the interviewee is in Table 2. 
Table 2. Basic information of interviewees.

\begin{tabular}{cccccc}
\hline \multicolumn{2}{l}{ Interviewee's proxy Gender } & Age & Education level & Occupation & Annual personal income \\
\hline A & Female & 56 & High school & Peasants & Under 10.000 RMB \\
B & Male & 61 & High school & Peasants & $10,000-30,000 \mathrm{RMB}$ \\
C & Female & 37 & High school & Enterprise workers & $30,000-60,000 \mathrm{RMB}$ \\
D & Male & 13 & Junior high school & Student & Under 10.000 RMB \\
E & Female & 21 & College & Student & Under 10.000 RMB \\
F & Male & 52 & College & $\begin{array}{c}\text { Government } \\
\text { workers }\end{array}$ & $30,000-60,000 \mathrm{RMB}$ \\
& & & & &
\end{tabular}

\subsubsection{Ethical Considerations}

Prior to the commencement of this project, the researcher completed a research ethics form under the University of Sheffield's research ethics guidelines. In addition, all participants were given an information sheet before participating in the study detailing the study's purpose, the researcher's role and their right to withdraw from the study at any time. Because the questionnaires were administered during the study in the resettlement plots where the landless peasants lived, the information sheets were also retained by the participating communities. All participants also signed the Participant Consent Form prior to the interviews, which ensured that the questions allowed for the recording of the interviews. Confidentiality and anonymity are crucial ethical considerations in research. Therefore, all participants were informed that the data they provided was anonymous and was kept strictly confidential.

\section{Analysis of the Current Situation and Reasons for Urban Adaptation of Landless Farmers in NUDs}

\subsection{Analysis of the Current Situation}

\subsubsection{Urban Adaptation of Landless Peasants in the Study Area in Economic Terms}

Occupational changes The occupational roles of landless peasants in the demolition and resettlement communities have changed. The change in the occupation of landless peasants can be seen in the change in the main source of income. Before resettlement, the main source of income for landless peasants was farming, accounting for $41.8 \%$ of the total. The main source of income was wage income, accounting for $34.02 \%$. After resettlement, the proportion of those whose main source of income was farming dropped to $4.1 \%$, a decrease of $37.7 \%$. There was a $25 \%$ increase in those whose source of income after resettlement was wage income. Although the majority of participants who were once mainly engaged in farming have joined the workforce after resettlement. However, there are still some landless peasants who face unemployment. Interviewee A then faced difficulties in finding a job.

"It's really embarrassing for us to be in our fifties. Everyone else wants to be under 50 when they go to look for work, and the policy requires you to be over 
60 to receive the old-age insurance subsidy. At my age, I m stuck here, I can't find a job and I can't receive the subsidy."

The types of occupations held by those participants who had jobs were mostly in the construction and manufacturing industries and the food and entertainment services. The most frequent reason for not working among those without an occupation was lack of skills, accounting for $38.11 \%$ of the total. The second most frequent reason was age, accounting for $27.05 \%$ of the total. Some participants answered in the fill-in-the-blank that the reason for not having a job was to take care of the family and look after children. Some of the participants expressed the hope that they could find suitable part-time jobs to take care of their families and earn a little income. To help landless peasants to take up jobs, the community provides vocational training (Tao \& Wu, 2018). However, $45.08 \%$ of the survey respondents had never attended vocational training. Regarding vocational training in the community, Landless Peasant B said

"I have only heard of one vocational training for elderly carers arranged by the community so far, but others only need women and I, a man, did not participate."

Of those surveyed who had jobs, a total of $60.25 \%$ relied on their own social connections and applied for jobs on their own initiative, and those who were introduced to jobs by their communities were four. However, community worker E stated at the time of the interview that

"The community often introduces suitable jobs to landless peasants, although the number of vocational training specifically conducted by the community is relatively small. Among the landless peasants who have jobs, many of them apply for jobs after being introduced through the community. It is possible that this group of people also chose the option 'apply for jobs on their own initiative' when they did the questionnaire."

Economic income and expenditure Employment and economic income go hand in hand. The survey found that $55.74 \%$ of the respondents reported no significant change in economic income. $33.2 \%$ reported a decrease in economic income, while $11.07 \%$ reported an increase in economic income. The fact that a significant proportion of landless peasants have seen their income decrease after resettlement needs to be taken seriously. Displaced peasant A also reported a significant decrease in income after resettlement.

"Before resettlement my family had machines for processing agricultural products. The money from processing agricultural products was the main income for my family. Farming was mainly for our own consumption and we only earned a little money. Now there is no more land to plant and the machines are not working, so basically, I have no income. We have to rely on the compensation money to make a living".

A comparison of annual expenses and annual personal income shows that within the same range of options, such as " 30,000 to 60,000 yuan", the proportion of expenses is greater than the proportion of income. This means that some 
of the dispossessed peasants are responsible for expenses that they cannot cover with their income. The main items that landless peasants spend on are, in descending order of frequency, "food purchase", "children's education", "medical care", "transport", and "health care", "transport", "rent, utilities", "furniture and clothing", "socializing", "cultural learning" and "socializing", "cultural studies" and "entertainment". Some participants added "insurance" to the list. When asked whether their consumption had increased after resettlement, $72.13 \%$ of participants said that their consumption had increased after resettlement. All three respondents, A, B and C, said that they felt that their consumption had increased after resettlement because food had to be purchased in urban life after resettlement, compared to the self-sufficiency of rural life. An additional expense that the researcher did not expect was mentioned by $\mathrm{B}$, the cost of water.

"In the old days in the countryside we had wells and ponds, and the level in there was used when washing vegetables and bathing. The earthen toilets in the countryside didn't need to be flushed either. When you choose to live inside a building now, you need water to wash everything, and it s a lot of money."

However, in response to the problem of rural toilets not flushing in the past, community workers said that with the "toilet revolution" (Wu, 2018), the choice of rural toilets has all been replaced with modern toilets. So even if the land had not been expropriated, the cost of water would have been unavoidable. In the last open-ended question of the questionnaire, the most frequently mentioned issue was that the property fees in the resettlement community were too expensive. When filling out the questionnaire, landless peasant $\mathrm{C}$ also said

"Before living in the countryside there was no property fee. This is just a completely extra expense for me. Yesterday I just paid the property fees for two houses for a year, together 1200 yuan. A lot of people inside our neighbourhood get paid that much a month."

After comparing property fees in the old urban districts, it was found that the property fees in the resettlement communities are the same as in the city.

Social security The survey data showed that participants were generally satisfied with the overall compensation outcome. $65.57 \%$ of the total number of participants were satisfied with the compensation outcome. Those who expressed dissatisfaction accounted for $34.43 \%$. With regard to the purchase of social insurance, $83.2 \%$ of landless peasants purchased medical insurance and $72.95 \%$ of landless peasants purchased pension insurance. The percentage of participants who had purchased other types of insurance was around $10 \%$ of the total survey, which is close to the percentage of those who chose "working in enterprises and institutions" under the questionnaire's occupation. This is because in China it is mainly enterprises and institutions that purchase multiple social insurance policies for their employees ( $\mathrm{Li}, \mathrm{Wu}, \&$ Meng, 2021). Five participants indicated that they had no insurance coverage at all. In the last open-ended question of the questionnaire, many participants responded that pension insurance was too expensive and unaffordable, and $\mathrm{B}$ also stated 
"Now I have to pay pension insurance every month, but the subsidy I receive is not much. It's much less than the pension allowance they get in the city. I only get $500 \mathrm{RMB}$ a month now, but the pension allowance for city dwellers can be two to three thousand $R M B$ a month."

The response from the community worker in the interview was that "not everyone in the city can get a high pension allowance. Only those who have worked in enterprises and institutions for many years and retired can get it, and these people pay more for their pension insurance than rural residents. The higher the investment, the greater the return.

\subsubsection{Social Aspects of Urban Adaptation among Landless Peasants in the Study Area}

Socially, $64.34 \%$ of the participants felt that their social range had not changed significantly compared to that before land acquisition. $56.56 \%$ of the participants indicated that the people they usually interacted with most were relatives and friends. $31.15 \%$ of the participants chose workmates. Regarding leisure time activities, the main activities chosen by the participants were "watching TV or relaxing at home", "playing on the mobile phone or surfing the internet" and "going for a walk or going shopping for parties". Communities in built-up districts often organise activities to enhance the well-being of residents (Liu, 2017), but $43.85 \%$ of participants in this survey said they never attended community events. $39.75 \%$ of participants said they did not know or care about community events. Only $13.93 \%$ of participants believed that community events were held regularly. Peasant A also said that "the only activity that the community has organised so far seems to be square dancing, but I have not heard of any other activities." Comparing the satisfaction with life of landless peasants before and after resettlement, it can be seen that the proportion of "very satisfied" and "more satisfied" has decreased. The corresponding percentages of "less satisfied" and "very dissatisfied" have increased slightly. However, overall satisfaction with the environment of the resettlement community is very high. $17.22 \%$ of the total number of participants were dissatisfied with the environment of the resettlement area. The satisfaction with the environment of the resettlement community was also reflected in other questions, such as "living conditions", which was chosen by $75 \%$ of the participants as the "aspect that they felt was better than in the past".

\subsubsection{Urban Adaptation of Landless Peasants in the Study Area in Terms of Self-Identification}

According to the survey data, $37.71 \%$ of the participants chose "disagree" to the question "I am already an urbanite", another $44.26 \%$ chose "not sure". A further $44.26 \%$ chose "not sure", while $18.03 \%$ identified themselves as urbanites. When asked if they had changed, $43.44 \%$ of the total number of participants chose "not sure". Figure 1 shows the distribution of the answers to the question "I am already a city resident".

When it came to the difference between rural and urban people, the number of participants who thought there was a difference was about the same as those 
who thought there was no difference. However, $62.71 \%$ of the participants agreed that the difference between rural and urban districts is very significant, while $15.16 \%$ disagreed. In terms of lifestyle $42.63 \%$ of participants said that they had largely adapted to urban life, while $46.31 \%$ considered themselves to be typical rural people. The percentage of participants who did not mind letting others know that they were from the countryside was $87.3 \%$. Overall, more people chose "not sure" for the question on self-identification than for the question on the rural and urban physical environment. Figure 2 shows the distribution of answers to the question "There is no difference between urban and rural people".

\subsection{Reasons for Urban Adaptation of Landless Farmers in NUDs}

"I am already an urbanite" is a very important question in self-identification, so the researcher cross-tabulated the other questions as independent variables (on the $\mathrm{x}$-axis of the chart) with this question, and the results were more evident in the following groups.

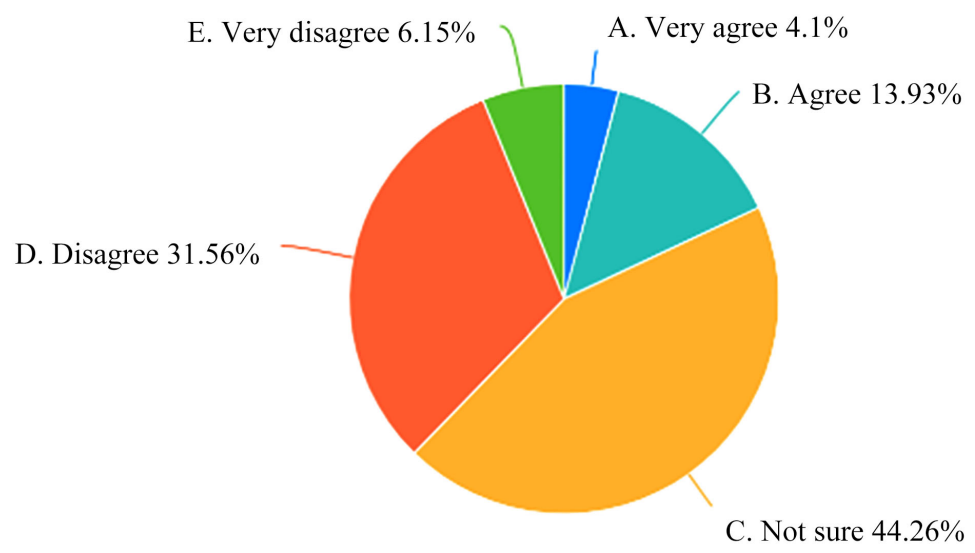

Figure 1. The distribution of answers to the question "I am already a city dweller".

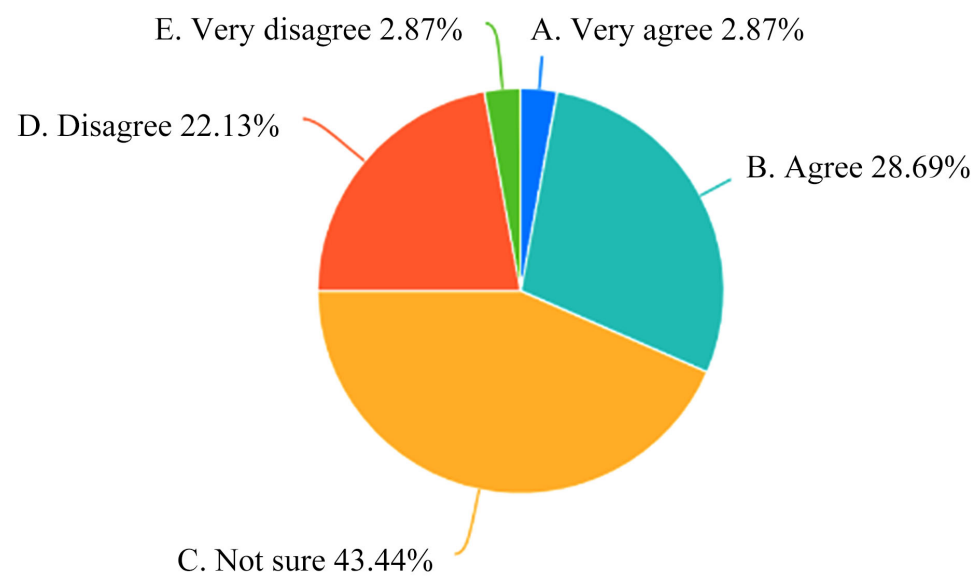

Figure 2. The distribution of answers to the question "There is no difference between urban and rural people". 
Cross-tabulations with the age of the participants showed that the proportion of those who strongly identified as urban was similar across the age groups (showing in Figure 3). However, the proportion of those who agree that they are more urban tends to increase overall with age. The proportion of those who disagreed that they were urban tended to decrease with age. This means that as the age of the participants increases, the more they identify themselves as urbanites. The interview revealed that this may be related to the different standards of urbanites in different age groups. Among the interviewees, only D did not identify himself as an urbanite; A and B, as older people, felt that they were urbanites because they lived in the city; $\mathrm{C}$, as a middle-aged person, felt that he was an urbanite because he worked in the city; $\mathrm{E}$, who grew up studying in a school in the city and lived there, considered himself an urbanite; D, as a university student in a big city, thought that he was very different from his classmates in the city in terms of economic power and living habits, etc. The largest proportion of people over 60 years of age consider themselves to be urbanites. However, the sample of over-60s in the questionnaire database is too small to be indicative. This result may be related to the choice of the study area. The study area, Jingmen, is not a provincial capital city itself, and the gap between citizens and peasants within the city is small. Therefore, people who spend a lot of time in their hometowns do not feel the urban-rural gap as much.

The results of the cross-tabulation analysis between "satisfaction with the environment of the resettlement community" as the independent variable and "perceiving themselves as urbanites" were very significant (shown in Figure 4). In other words, the higher the satisfaction with the environment, the more they recognise themselves as urbanites. Therefore, optimising the resettlement environment has a positive effect on the self-identity of the displaced peasants.

The cross-tabulation of "satisfaction with the outcome of compensation" as the independent variable with "perception of being an urbanite" leads to the conclusion that the formulation of a reasonable compensation policy also has a positive effect on the self-identification of landless peasants (shown in Figure 5).

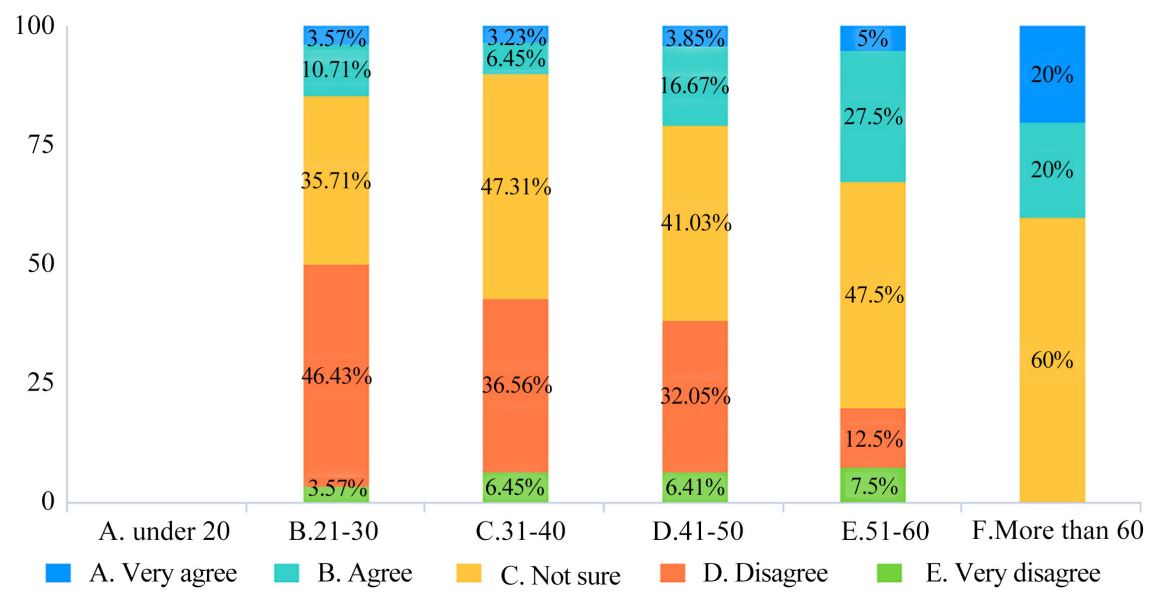

Figure 3. Results of the cross-tabulation of data from the items "Age" and "I am already an urbanite". 


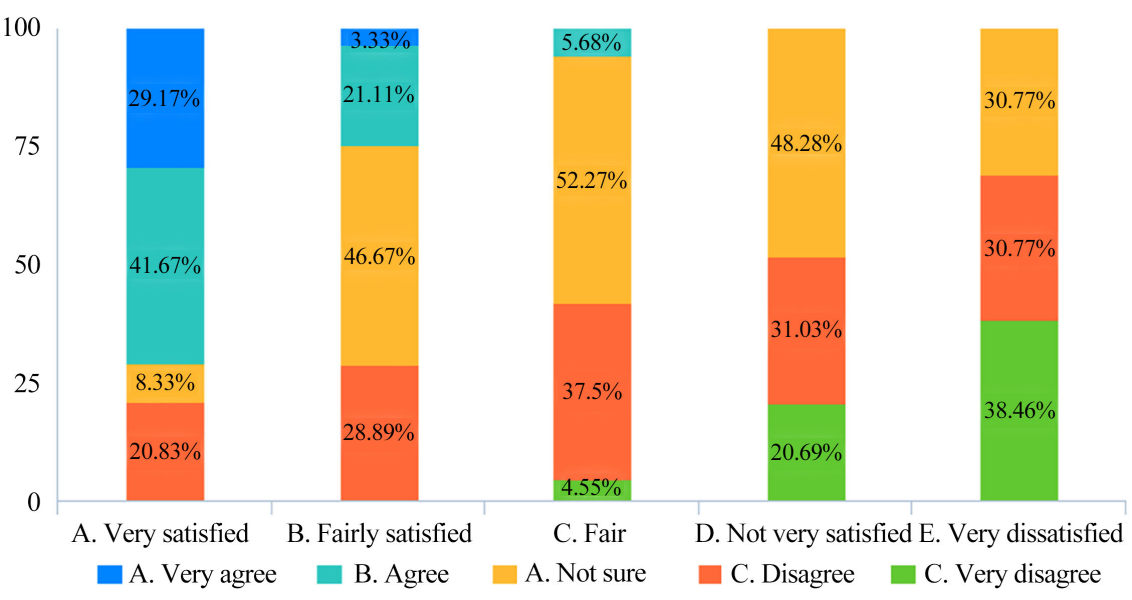

Figure 4. Results of the cross-tabulation of data from the items "satisfaction with the environment of the resettlement community" and "I am already an urbanite".

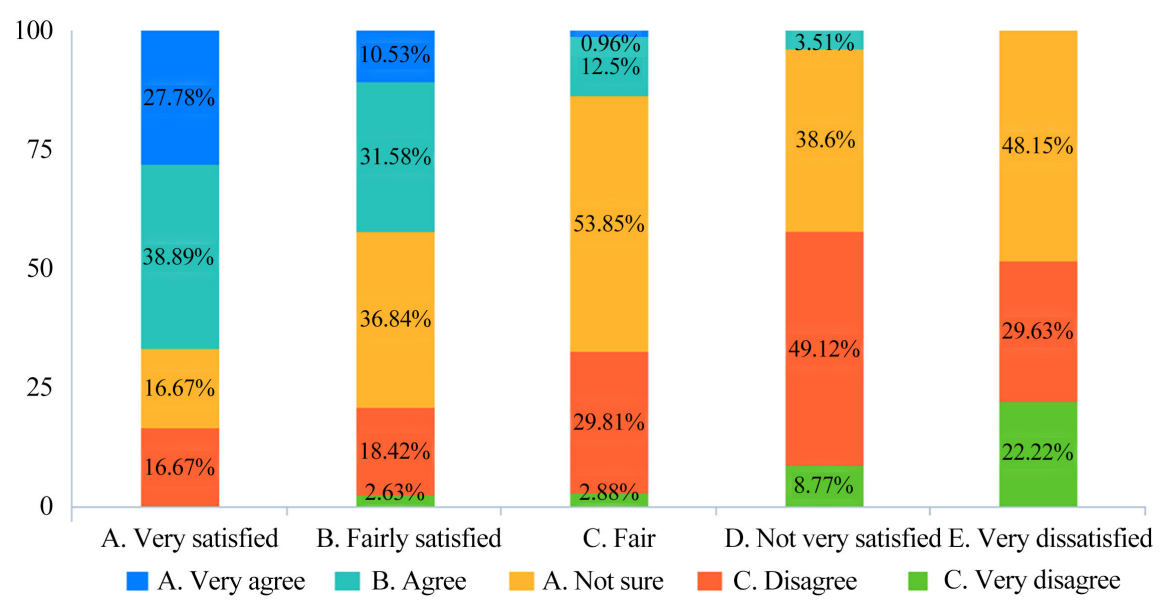

Figure 5. Results of the cross-tabulation of data from the items "satisfaction with the outcome of compensation" and "I am already an urbanite".

\section{Discussion}

\subsection{Employment}

\subsubsection{Analysis of the Employment Situation of Landless Peasants}

Employment is difficult In terms of employment status, this study found that some of the landless peasants face unemployment difficulties. This situation is the same as the findings of past research studies in different provinces and cities. The results of the study show that after losing their land, peri-urban peasants mainly solve their employment problems through market-based employment and self-employment. Some landless peasants face significant employment difficulties due to their lack of skills, age and low education (Wang, Chen, \& Wang, 2017). The unemployment rate of landless peasants ranges from $15 \%$ to $30 \%$ (Chen, Wang, \& Zhang, 2014).

Low quality of employment Questionnaire data show that peasants' income from farming operations on the land is significantly reduced after losing their land, with employment wages becoming the main source of household income. 
However, landless peasants have few employment options, and those that they do find are often temporary and simple. As a result, although the share of wage income in total household income has increased considerably, the actual monthly wage is quite limited (Song, Sun, \& Cui, 2013). Several research experiments have demonstrated that the average monthly employment income of landless peasants is generally low in terms of real life needs (The Development Research Center of the State Council, 2009; Cheng \& Du, 2011).

\subsubsection{How to Help Landless Peasants Find Employment}

There are both individual and social reasons for the employment difficulties of landless peasants. In addition to the individual reasons mentioned above, social reasons include the immaturity of the employment training system, the lack of preferential policies for employment and entrepreneurship, and so on. It is difficult for landless peasants to solve the problem of employment by their own efforts and, compared to migrant peasants, landless peasants have a less subjective sense of employment oppression. As the urbanisation process is government-led, landless peasants have strong expectations and dependence on the government in terms of employment. The government should take up the responsibility of promoting the employment of landless peasants. It can help landless peasants to find employment in the following ways. First, in terms of land acquisition use, it should favour development projects with high employment opportunities, high employment levels and a strong regional employment and entrepreneurship drive (Liu, 2012). The employment problem of landless peasants can be solved at source. Second, establish and improve an induction training system for landless peasants, co-ordinate training funds and integrate local vocational training resources. And there should be appropriate vocational training for different genders and age groups. Thirdly, we should encourage landless peasants to take up independent employment and formulate preferential policies. The government should support landless peasants to take up self-employment in terms of capital, space, taxes and fees, and technical guidance, so as to reduce the risk of starting a business.

\subsection{Income and Expenditure}

\subsubsection{Analysis of the Income and Expenditure Situation of Landless Peasants}

Reduced income The reduced income of some landless farmers after resettlement is on the one hand a result of the employment situation mentioned above. On the other hand, due to the relatively low compensation and resettlement standards for land expropriation in China, they are not sufficient to support the long-term livelihoods of landless farmers.

Increased expenditure On the expenditure side, after land expropriation, the entire livelihood of landless farmers is integrated into the same market system as that of citizens. The cost of living has increased significantly. For example, the cost of purchasing food and property costs mentioned in the research 
interviews.

The study's data shows that the consumption of dispossessed farmers is subsistence-oriented. Developmental and enjoyment consumption is underrepresented. This result is consistent with the results of an experiment conducted by Liu Juan in the Qing Yuan community in Suzhou (Liu, 2012). The consumption of dislocated farmers is mainly that which is necessary for living. This indicates that the overall quality of life of landless farmers is not high.

\subsubsection{How to Improve the Economic Situation of Landless Peasants}

The solution to the employment problem can effectively improve the economic situation of landless farmers. In addition, the development of the collective economy of the suburban villages and the development of suburban industries will stimulate the economic vitality of the suburban economy and increase the dividends of the collective economy.

\subsection{Social Security}

\subsubsection{Analysis of the Social Security Situation of Landless Peasants}

Social security benefits upgrade Throughout China, the social security schemes for landless peasants are mainly based on the provision of a certain degree of old-age security, with landless peasants receiving a monthly pension when they reach retirement age. The monthly pensions received by landless peasants vary across China, ranging from $500 \mathrm{RMB}$ to $1000 \mathrm{RMB}$ (Jiang, $\mathrm{Hu}, \&$ Miao, 2011; Cheng \& Du, 2011; Zhang, 2012). To a certain extent, these pensions alleviate peasants' worries when they lose their land security and allow them to maintain their basic livelihoods in old age. In addition, in many places, the government has funded medical insurance for peasants according to their employment situation after losing their land, so as to reduce the burden of medical expenses for peasants who have lost their land.

Social security benefits are lower than those of urban residents The social security benefits of landless peasants are far lower than those of urban retirees, and cannot fully meet the needs of their old age. At the same time, there is still the problem of high contribution standards in the implementation of social security systems in various regions. In terms of pension insurance contribution rates alone, the highest individual contribution rate is $65 \%$, and even lower ones are at least $20 \%$. Contributions of tens of thousands or even tens of thousands of dollars are indeed a heavy burden for landless peasants. This was also mentioned in the open-ended questions in the questionnaire and in the answers to the interviews.

\subsubsection{How to Strengthen Social Security for Landless Peasants}

The state should actively implement urban-rural integration and integrate landless peasants into the urban social security system. In terms of employment, housing, education, pensions, medical care and infrastructure, equality should be achieved between suburban landless peasants and urban residents. Firstly, the 
government should increase financial input and reduce the burden of individual contributions (Yi, Xiao, \& Chen, 2011). Secondly, the social security system should be improved. Third, improve the monitoring system to ensure the effective operation and timely disbursement of funds.

\subsection{Social Life}

\subsubsection{Analysis of the Social Life Situation of Landless Peasants}

Social network limitations Relationship networks in modern urban societies are generally based on occupation (Zhong, Li, \& Yu, 2009). The landless farmers in this study are all generated by the construction of new urban areas, which are characterized by the local resettlement of landless farmers in their original residential areas. In other words, the neighbours of the landless peasants in this study remained more or less the same before and after resettlement, but only the density of living changed. The participants in the survey mainly interacted with relatives and friends. This result is also related to the nature of Chinese villages. The basic unit of traditional Chinese society is the family. In terms of settlement patterns, the family is a "clan", and villages are mostly the result of family clustering and reproduction (Huang, 2001). Therefore, many people in the same village are related to each other.

A single form of leisure In terms of lifestyle, landless peasants who have moved to urban communities still retain their rural habits and lifestyles to a large extent. Although landless peasants have become more exposed to urban life during the urbanisation process and have imitated urban residents in their daily lives, this imitation and pursuit of urban lifestyle is more materialistic and superficial, and they have not developed a sense of role that corresponds to their citizenship. However, this imitation and pursuit of the urban lifestyle is more materialistic and superficial, and does not lead to a sense of role and values corresponding to citizenship.

After land expropriation, landless peasants, especially the older ones, have more leisure time, but they still mainly spend their leisure time at home watching television, chatting with neighbours or playing cards and mahjong, which is relatively homogeneous compared to the leisure time of urban residents. It is evident that, under the long-term influence of traditional agricultural production methods and the corresponding lifestyle habits, landless peasants are unable to adapt to the fast pace and diverse lifestyles of the city in the short term.

\subsubsection{How to Help Landless Farmers Adapt to Urban Life}

Further optimise the construction of social capital networks, break the spatial

Geographical constraints, effectively expand the social networks of passive and active landless farmers, and enhance their social capital tensions in line with the urbanisation process. For example, in the process of urbanisation, landless peasants can try to build a social capital network with urban employment, urban community cultural life and political participation as attachment points, so that they can better integrate into the city and improve their living standards. 


\subsection{Self-Identity}

\subsubsection{Current Status of Self-Identity}

Some scholars have used self-identity as a starting point to discuss the urban adaptation of landless peasants, arguing that the hallmark of urban adaptation for landless peasants is the complete transformation of self-identity (Zhang \& Tong, 2006). However, self-identity and identity are not identical concepts, and this has been confused in some previous studies. Landless peasants in new urban districts are not very willing to change their identities, and there is no compulsory government requirement to do so. Landless peasants within the built-up area began to enjoy city-related welfare policies, such as pension insurance and medical insurance, regardless of whether their status changed. The minimum living standards have also begun to be brought into line with those of urban residents. So, the change of status has little impact on urban adaptation. According to the research data, the current self-identity of some landless peasants is rather ambiguous. Landless peasants "not sure" who they really are.

\subsubsection{Factors Influencing Self-Identity}

As for the analysis of influencing factors, the main ones are: first, individual factors such as age, gender, years of education and psychological preferences also combine to influence the urban integration of landless peasants (Yin \& Chen, 2014). Second, government policies that encourage the endogenous development of landless peasants contribute to their urban integration ( $\mathrm{Du} \& \mathrm{Xu}, 2016$ ). Third, there are significant differences in the impact of social interactions on the psychological integration of different types of migrant populations (Wang \& Yuan, 2016). The cross-sectional analysis in this study showed that age, resettlement community environment, and compensation policy all had an impact on the self-identity of landless farmers. This is in line with the findings of other scholars' previous studies. Most of the landless peasants do not share the same traditional identity and tendency to belong in the future, which is directly due to the fact that they are passively urbanised. The more fundamental and deeper reasons for this need to be analysed and understood in the context of the social structure of contemporary Chinese social change. The unique institutional arrangements and the changing social practice context, such as the urban-rural dichotomy, the rapid change from traditional to modern society, the dual-track system of the planned and market systems, have blurred the traditionally clear identity boundaries of both landless and migrant peasants, making them different from both traditional peasants and modern citizens. What is their future? "Modernity is the production of difference, exception and marginalisation" (Fang \& Ma, 2013). The marginalisation of the dislocated peasants' inner selves is predictable.

\section{Conclusion}

This study explores the urban adaptation of landless peasants in the construction 
of new urban districts and the factors that influence the urban adaptation of landless peasants. This was explored through an empirical analysis of the urban adaptation of landless peasants in the Zhanghe New District in Hubei Province, China. This study adopts a combination of qualitative and quantitative research methods. It also takes into account the micro feelings of the individuals studied. A theoretical framework for assessing the urban adjustment of landless peasants in the construction of NUDs in terms of three dimensions: economic, social and self-identity, was finally confirmed. Overall, this study reveals that the urban adaptation of landless peasants is multidimensional. The interviews allow for a more in-depth analysis of the reasons behind the current situation and the actual situation of the landless peasants. The discussion will be divided into three parts based on the theoretical framework, addressing three aspects: economic, social and self-identity. A comprehensive and insightful analysis of the urban adaptation of landless peasants in the construction of NUDs is presented. At the same time, the plight of landless peasants in urban construction and the imperfections of policies and institutions are revealed. Then some explanations emerge, and some means of solution are proposed. The ultimate endpoint of urbanisation is the urbanisation of people. Landless peasants arising from the construction of NUDs encounter additional dilemmas as they are passive in their identity transformation. This study can therefore delve into the specific causes of urban adaptation and propose targeted solutions. This study will provide some references for the promotion of urbanisation in China.

Firstly, the economic aspects of urban adaptation of landless peasants due to the construction of NUDs are examined. The study focuses on three specific directions: occupational change, economic income and expenditure, and social security. First, the occupational role of landless peasants changed after resettlement. After land expropriation, peasants are forced to face the dilemma of unemployment. The difficulties they face in finding jobs are mainly due to their age, lack of skills and low education. Therefore, they can often only find simple labour with low pay. In order to solve this problem, the state should favour employment-friendly projects when building new districts to solve the problem at its root. The vocational training system should also be improved. At the same time, preferential policies can be introduced to encourage landless peasants to start their own businesses. Secondly, the change of occupation also affects the economic income of landless peasants. Some landless peasants have more sources of income but less total income. At the same time, the expenses of landless peasants increase after resettlement because of the change in their rural subsistence lifestyle. Therefore, on top of solving the employment problem, the state can also develop the collective economy of the resettlement communities and give benefits to the landless peasants. Third, in terms of social security, most landless peasants have taken out pension and medical insurance. However, many participants say that the amount of money they have to pay for insurance is too high to afford. Therefore, the state should increase its financial investment 
and, at the same time, strengthen regulation.

Secondly, from a social perspective, most of the displaced peasants in the NUDs have been resettled collectively on the spot. Most landless peasants say that their social network has not changed much, but they live with relatives and friends. The usual leisure activities are also mainly watching TV and shopping, with less cultural and recreational activities. The community should organise more cultural and recreational activities in response to this situation so that the dispossessed peasants can adapt to urban life in terms of lifestyle and spiritual core. Most of the dispossessed peasants said they were satisfied with the internal environment of the resettlement community. However, as the construction of NUDs is a long process, the dispossessed peasants will go through an awkward phase where the public facilities around them are not supported. For this reason, the state should plan rationally at the time of the establishment of the new district and include the construction of facilities around the resettlement community as a key consideration.

Finally, the self-identity of the displaced peasants is related to their age, the environment of the resettlement community and the compensation policy. In other words, the psychological citizenship of dispossessed peasants is also influenced by the external environment. Several studies have shown that there are significant intergenerational differences in the self-identity of landless peasants. This is a natural result of different life experiences.

Nevertheless, at the material level, a good resettlement environment and a generous compensation policy contribute positively to landless peasants' self-identity. Moreover, a good self-identity of landless peasants contributes significantly to the stability and harmony of society as a whole. Additionally, urbanisation ultimately comes down to the urbanisation of people. Therefore, future researchers and community workers in resettlement communities should pay more attention to the micro-emotional expressions of landless peasants. Furthermore, they should analyse the factors that can influence their self-identity to target their efforts to help landless peasants complete the transformation of their inner core.

\section{Conflicts of Interest}

The author declares no conflicts of interest regarding the publication of this paper.

\section{References}

Baumbusch, J. (2010). Semi-Structured Interviewing in Practice-Close Research. Journal for Specialists in Pediatric Nursing, 15, 255-258. https://doi.org/10.1111/j.1744-6155.2010.00243.x

Bray, D (2013). Urban Planning Goes Rural: Conceptualising the "New Village". China Perspectives, 95, 53-62. https://doi.org/10.4000/chinaperspectives.6273

Chai, L. Y., Li, X., \& Liu, Y. (2021). Progress of Research on Mental Health of Landless New Town Residents in China. Journal of Jining Medical College, 44, 281-285.

Chanyeguihua.com. (2021). Planning of New Urban Districts. 
http://www.chanyeguihua.com/index40.html

Chen, A. (2020). The Impact of Land Requisition on Peasant Life in China. Modern China, 46, 79-110. https://doi.org/10.1177/0097700419839638

Chen, D., Wang, S. L., \& Zhang, O. X. (2014). Analysis of Factors Influencing the Re-Employment of Landless Peasants in the Urbanization Process. Research World, No. 7, 40-44.

Cheng, D. L., \& Dong, K. Y. (2004). A Study on the Factors Influencing the Labor Supply of "Landless Peasants" in the Urban-Rural Area (Beijing). Economic Science, No. 4, 63-71.

Cheng, T. S., \& Du, F. F. (2011). The Problem of Landless Peasants in the Process of Rapid Urbanization: The Example of "House Base for House" in Huaming Town, Tianjin. Journal of Chongqing Socialist College, No. 3, 93-96.

Du, S. Y., \& Xu, J. X. (2016). Research on Sustainable Livelihood Dilemmas of Landless Farmers and Cracking Mechanisms under the Perspective of Endogenous Development. The Economist, 7, 76-83.

Fang, C. L. (2009). Resource and Environmental Security Problems in China's Rapid Urbanization and Suggestions for Countermeasures. Proceedings of the Chinese Academy of Sciences, No. 5, 468-474.

Fang, C. L., \& Ma, H. T. (2013). Construction of New Districts and Intensive Land Use in China in the Context of New Urbanization. China Land Science, 27, 4-9.

Ge, J. T. (2004). The Problem of Landless Peasants in China's Urbanization Process. Shandong Social Science, No. 8, 47-50.

Han, D. (2019). Identity and Urban Adaptation of Landless Peasants. Social Science Series, No. 2, 52-55.

Heger, I. (2018). Same Land, Different Life? Questioning Narratives Surrounding.

Heger, I. (2020). More than "Peasants without Land": Individualisation and Identity Formation of Landless Peasants in the Process of China's State-Led Rural Urbanisation. Journal of Current Chinese Affairs, 49, 332-356.

https://doi.org/10.1177\%2F1868102620915000

Howard, E., \& Osborn, F. J. (2006). Garden Cities of To-Morrow. Routledge.

Huang, T. (2001). The Proposed Kinship System and "Family-Like" Villager Relationship in Villages. Journal of Renmin University of China, 2, 101-105.

Jiang, J., Hu, S. J., \& Miao, W. D. (2011). A Study on the Current Situation of Citizenship of Landless Peasants in Suburban Beijing: The Case of Laiguangying Village. Journal of Beijing University of Technology: Social Science Edition, 11, 7-15.

Jin, J. (2017, December 19). Umsiedlung in China: Der große Stadtplan [Relocation in China: the big urban plan]. Zeit Online.

https://www.zeit.de/2017/53/china-wachstum-wohlstand-umsiedlung-bauern-hochhae user

Johnson, I. (2013). China's Great Uprooting: Moving 250 Million into Cities. The New York Times, 15 June.

Kirby, A. (2003). Redefining Social and Environmental Relations at the Ecovillage at Ithaca: A Case Study. Journal of Environmental Psychology, 23, 323-332. https://doi.org/10.1016/S0272-4944(03)00025-2

Lai, D. S. (2011). China's Labor Market Report 2011: Under the Background of Inclusive Growth of Employment Quality. Beijing Normal University Press.

Li, L., \& Tian, H. (Eds.) (2014). Report on the Development of the Rule of Law in China. 
Chinese Academy of Social Sciences. https://doi.org/10.1177/0042098011411947

Li, S., Wu, S. S., \& Meng, F. Q. (2021). "Do the Five Insurance and One Pension” Widen the Income Inequality of Urban Workers? Social Science Series, No. 2, 73-87.

Li, Y. (2006). Towards the City of Reason: Development and Growth Control of New Urban Districts in Rapid Urbanization. China Construction Industry Press.

Li, Y. P. (2004). An Empirical Investigation and Analysis of the Survival Situation of Landless Peasants in Hangzhou Suburbs during Urbanization. Journal of the Party School of the Hangzhou Municipal Committee of the Communist Party of China, 2, 37.

Liu, J. (2012). Study on Urban Adaptation of Landless Peasants from Social Work Perspective. Master's Thesis, Soochow University.

Liu, R. (2017). A Study on the Satisfaction of Residents in Demolition and Resettlement Communities and Its Influencing Factors. Master's Thesis, Northwest A\&M University.

Lora-Wainwright, A. (2014). Grassroots Perspectives on Relocation: Threats and Opportunities. Positions: Asia Critique, 22, 661-689.

https://doi.org/10.1215/10679847-2685413

Mocetti, S., \& Porello, C. (2010). How Does Immigration Affect Native Internal Mobility? New Evidence from Italy. Regional Science and Urban Economics, 40, 427-439.

National Development and Reform Commission (2016, May 5). Planning Policy (2014-2020).

https://www.ndrc.gov.cn/xwdt/ztzl/xxczhjs/ghzc/201605/t20160505 971882.html?code $=$ \&state $=123$

Pope, C., Ziebland, S., \& Mays, N. (2000). Analysing Qualitative Data. BMJ, 320, 114-116. https://doi.org/10.1136/bmj.320.7227.114

Ren, L. M., \& Xie, J. D. (2008). Problems and Suggestions of the Current Land Approval System. Zhejiang Land and Resources, No. 10, 36-39.

Rosenberg, L. (2013). Urbanising the Rural: Local Strategies for Creating "New Style" Rural Communities in China. China Perspectives, 95, 63-71.

Schneider, M. (2015). What, Then, Is a Chinese Peasant? Nongmin Discourses and Agroindustrialization in Contemporary China. Agriculture and Human Values, 32, 331-346. https://doi.org/10.1007/s10460-014-9559-6

Shan, Z., \& Huang, Y. P. (2013). The Connotation of the Concept of "New Urbanization", Its Objectives, Planning Strategies and Misconceptions. Journal of Urban Planning, 2, 16-22.

Song, J. H., Sun, G. X., \& Cui, K. (2013). A Review of Research on the Income of Landless Peasants. China Agricultural Resources and Zoning, 34, 198-204.

Tang, Y. F., \& Xie, X. Y. (2018). Attribution of Psychological Barriers to Urban Integration among Suburban Landless Peasants and Policy Interventions-An Analysis Based on Rooting Theory. Comparative Economic and Social Systems, 6, 148-161.

Tao, J. M., \& Wu, S. Q. (2018). A Review of Research on Vocational Training for Landless Peasants. China Adult Education, No. 10, 151-155.

The Development Research Center of the State Council (2009). Protection of the Rights and Interests of Landless Peasants in China and Some Policy Recommendations. Reform, 5, 5-16.

Wang, D., \& Christiansen, F. (2019). The Pursuit of New Citizenship by Peri-Urban Residents in China: Status, Rights, and Individual Choice. China Information, 34, 250-269. https://doi.org/10.1177/0920203X19835455 
Wang, H. (2011). Discussion on the Construction of New Urban Districts Based on the Background of Rapid Urbanization. Engineering and Construction, 25, 451-453.

Wang, L., \& Yuan, X. (2016). A Study on the Impact of Social Interactions on Psychological Integration among Mobile Populations. Tianfu New Theory, 1, 120-127.

Wang, X. H., \& Zhu, L. (2014). Landless Peasants' Identity and Its Differentiation-An Explanation Based on the Life Course Paradigm. Zhongzhou Journal, No. 4, 67-72.

Wang, Y., Chen, J. W., \& Wang, Q. (2017). Can Human Capital and Social Capital Improve the Employment Level of Landless Peasants-Based on Survey Data from Continuous Follow-Up in Beijing. Economic Theory and Economic Management, No. 4, 42-59.

Wang, Y., Zhan, P., \& Jiang, Z. (2018). Study on the Income Gap between Landless Peasants and Urban Residents and Non-Landless Peasants in the Process of Urbanization-Based on Survey Data in Beijing. China Rural Economy, No. 4, 121-139.

Wu, L. Y. (2005). Planning Research-A Study on the Preservation of Beijing's Old City (in Chinese). Beijing Planning and Construction, No. 1, 18-28.

Wu, S., \& Qin, Q. W. (2008). Progress of Research on Identity of Landless Peasants in the Process of Urbanization. Anhui Agricultural Science, 36, 10193-10196.

Wu, W. X., Yang, Y. C., Ma, J., \& Mao, L. (2005). A Study of Urban New Town (District) Development in China: The Case of Yuzhong New District, Lanzhou City. Urban Issues, No. 3, 20-25.

Wu, Z. X. (2018). Study on the Path of Rural Toilet Revolution in the Context of Rural Revitalization Strategy. Henan Agriculture, 11, 85-86.

Yi, X. Y., Xiao, B. L., \& Chen, Y. J. (2011). Current Status, Problems and Policy Recommendations of Agricultural Land Use Right Transfer Based on Peasants' Survey. China Agricultural Resources and Zoning, 32, 42-47.

Yin, J., \& Chen, T. H. (2014). Analysis of the Urban Integration Level of Landless Farmers and the Influencing Factors-Based on Survey Data in Wuhan City. Northwest Agriculture and Forestry University Journal, 5, 102-108.

Zhai, W. M., Huang, X. J., Zhang, Q., Zhou, F., Ma, Q. F., \& Zhong, T. Y. (2006). A Study on the Potential of Land Intensive Use in Urban Development Districts: A Typical Development District in Jiangsu Province as an Example. Resource Science, 28, 54-60.

Zhang, H. B., \& Tong, X. (2006). Self-Identity in Urban Adaptation and Modernity Acquisition among Passively Urbanized Groups. Sociological Research, 2, 86-106.

Zhang, J. H. (2012). Problems and Coping Strategies of the "Jiaxing Model" for Resettlement of Landless Peasants. Journal of Jiaxing College, 24, 56-61.

Zhang, R. L. (2004). From Active Marginalization to Passive Marginalization-A Study on the Urbanization Behavior of Agricultural Workers Who Have Changed Jobs. Agricultural Economic Issues, No. 3, 36-39.

Zhang, Z. Y. (2013). Building a People-Oriented Urbanization-Summary of Premier Li Keqiang's Q\&A with Chinese and Foreign Journalists. Urban Development, 3, 10-11.

Zhanghe New District Management Committee (2021). District Information. http://zhanghe.jingmen.gov.cn/

Zhong, Z. B., Li, F., \& Yu, J. Z. (2009). A Sociological Analysis of Urban Adaptation of Landless Peasants in the Process of Urbanization-A Perspective Based on Parsons' Social Action Theory. Rural Economics, No. 2, 104-107.

Zhu, M. J., \& Zhou, C. S. (2013). Advances in Theoretical Research on the Development of New Urban Districts at Home and Abroad. Tropical Geography, 33, 363-372. 